\title{
Indice delle tabelle
}

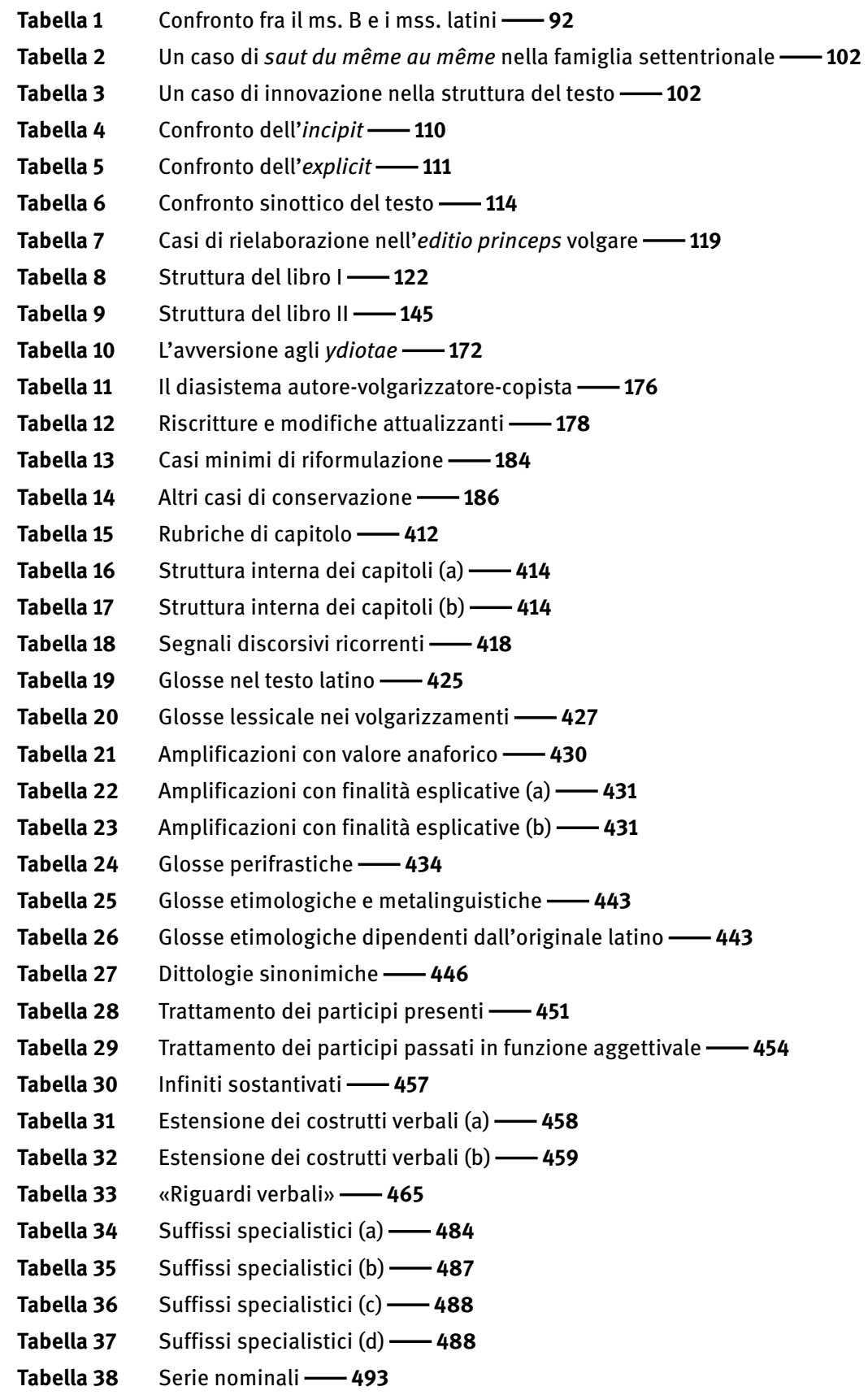


